\title{
HERDEIROS DE HEGEL? HISTORIOGRAFIA, FILOSOFIA POLITICA MODERNA E ANTIPAPAS MEDIEVAIS (1040-1140)
}

\section{HEIRS OF HEGEL? HISTORIOGRAPHY, MODERN POLITICAL PHILOSOPHY AND MEDIEVAL ANTIPOPES (1040-1140)}

RESUMO: A palavra antipapa é recorrentemente encontrada no vocabulário dos estudiosos da Idade Média. Antigo e familiar, este termo, todavia, esconde uma atitude intelectual repleta de implicações para o conhecimento do passado. Impregnado de julgamentos, ele nos induz a qualificar, de modo imediato e frequentemente acrítico, o significado histórico de sujeitos, conflitos de poder e relações sociais decisivas para a constituição política da Sé Romana e da Cristandade, sobretudo da assim chamada "Reforma Gregoriana". Trata-se de uma terminologia difundida, empregada de maneira corrente para enquadrar historicamente a política papal medieval. Entretanto, os estudiosos raramente 0 interrogam a respeito das implicações intelectuais que carrega para dentro da operação historiográfica. Este artigo consiste num breve exercício de problematização desta questão.

PALAVRAS-CHAVE: Antipapas; Historiografia; Hegel.

ABSTRACT: The word antipope integrates the basic vocabulary of every scholar of the Middle Ages. Old and familiar, this term, however, hides an intellectual attitude full of implications for the understanding of the past. Full of judgments, it induces to qualify, automatically and uncritically, the historical significance of individuals, conflicts of power and social relations crucial to the political constitution of the Roman See and Christianity, especially the so-called "Gregorian Reform". It is a widespread terminology, used to frame historically the medieval papal policy. But, scholars rarely wonder about the intellectual implications that it carries into the historiographical operation. This article is a brief exercise of questioning about this matter.

KEY WORDS: Antipopes; Historiography; Hegel.

(recebido em 19/01/2013, aprovado em 12/05/2013)

1 Doutor em História (UFF), Pós-Doutorando em História (USP). Pesquisador-fundador do Vivarium - Laboratório de Estudos da Antiguidade e Medievo. Docente do Programa de Pós-Graduação da Universidade Federal de Mato Grosso. Autor de "Colunas de São Pedro: a política papal na Idade Média Central" (Annablume, 2011). E-mail: leandrorust@yahoo.com.br. 
"A Justiça, aborrecida pelos crimes da Ambição, prepara o golpe que o Progresso fatal corta". Manoel C. P. de Aguiar, 1817.

\section{Um século de Antipapas}

Talvez eles passem por desconhecidos para alguns leitores da História Medieval, mas os "antipapas" foram personagens cruciais da Cristandade dos séculos XI e XII. Seu protagonismo político foi estrondoso. As notícias sobre suas ações alimentaram rumores por todo o mundo cristão, levando fulgor a muitos ouvidos, de Constantinopla a Dublin. Não era para menos. Afinal, este nome designava os eclesiásticos que teriam estremecido a unidade daquela sociedade; homens que desafiaram a legitimidade papal ao se intrometer na sucessão apostólica. Proclamando a plenos pulmões que a voz de São Pedro ecoava de suas gargantas, eles ousaram reivindicar a autoridade de pontífice quando outro prelado já havia sido aclamado ou eleito para exercê-la. Sua audácia perante as regras do direito canônico deformava os contornos essenciais da correta ordem jurídica almejada por seus contemporâneos. Sua ambição pelo poder universal dos bispos de Roma espezinhava a espiritualidade da época. Seus lábios derramavam palavras de fé apenas para aplicá-las como verniz de suas devastadoras intenções de dominação. Ao menos é isto que dizem os historiadores há alguns séculos. ${ }^{2}$

O período compreendido entre as décadas de 1040 e 1140 foi palco do recorrente aparecimento de personagens deste tipo. Nenhum outro contexto é capaz de rivalizar com este quando se trata de "antipapas". Segundo o Annuario Pontificio, ao longo de mais de dois milênios de História da Igreja existiram 39 "falsos reclamantes" do título papal. ${ }^{3}$ Dos quais, 12 viveram no recorte cronológico aqui destacado: Gregório VI (João Graciano, 1045-1046); Silvestre III (João Crescenzi, 1045-1046);

2 BARONIO, Cesare. Annales Ecclesiastici. Londres: Typographi Editores, 1869, t. $17-18$ (obra de 1588); PANVINIO, Onofrio. Romani Pontifices et Cardinales S. R. E. Ab eisdem a Leone IX apud Paulum papam IIII. Michaelem Tramezinum, 1557, sobretudo páginas 79-199 e 411-436; ANASTASIO, Ludovico A.. Istoria Degli Antipapi. Nápoles: S. Muziana, 1754, t. 1, p. 166-209; t. 2, p. 1-114; ZIGARELLI, D. M. Storia degli Antipapi e di Taluni Memorabili Avvenimenti delle Epoche rispettive dello Scisme. Nápoles: G. Gioja, 1859. Para as recentes definições ver: VAUCHEZ, A.ndré (Ed.). Encyclopedia of Middle Ages. Cambridge: James Clark, 2000, vol. 1, p. 75-76; LEVILLAIN, Philippe (Ed.). Dictionnaire Historique de la Papauté. Paris: Fayard, 2003, p. 118.

Compor uma lista de "antipapas" é uma tarefa controversa, devido à extrema variedade de critérios e à conflitualidade de categorizações existentes entre a historiografia eclesiástica, os historiadores modernos - entre os quais predominou inúmeras perspectivas teológicas - e a própria ortodoxia católica. O conjunto de "falsos pontífices" pode variar de 29 nomes - segundo o cômputo pioneiro do célebre canonista e cardeal Joseph Hergenröther - até um total de 42. A relação aqui indicada teve por base a versão oficial da Igreja Romana formalizada no século XIX por Pio XI: ANNUARIO PONTIFICIO. Roma: Tipographia Della R. C. A., 1861. Ver ainda: HERGENRÖTHER, Joseph. Handbuch der Allgemeinen Kirchengeschichte. Freiburg: B. Berlagshandlung, 1876, vol. 1 e 2. 
Bento X (João Míncio, 1058-1059); Honório II (Cádalo de Parma, 1061-1064); Clemente III (Guiberto de Ravena, 1081-1100); Teodorico (1100-1101); Alberto (1101); Silvestre IV (Maginulfo, 1105-1111); Gregório VIII (Maurício de Braga, 1118-1121); Celestino II (Teobaldo Bucapeno, 1124); Anacleto II (Pedro Pierleoni, 1130-1138); Vitor IV (Gregório Conti, 1138).

A lista é reveladora. Pois ela indica que uma sucessão de fracassadas tentativas para apoderar-se da Igreja romana entrecortou sem trégua o transcorrer de um processo político que os medievalistas não cessam de engrandecer: a chamada "Reforma Gregoriana" ou "Revolução Papal". As duas expressões apresentam diferentes compreensões a respeito de um mesmo desfecho da história ocidental. Apesar das intermináveis divergências semeadas em seus usos, os estudiosos concordam que ambas convergem para a mesma conclusão: a de que na passagem do século XI para o século XII a figura do bispo de Roma alcançou um significado político inédito. A influência concreta de sua autoridade teria pesado sobre o cotidiano das populações medievais como nunca. Foi então que suas decisões passaram a repercutir sobre os comportamentos com uma eficácia e uma frequência desconhecidas até mesmo nos tempos de Constantino ou de Carlos Magno. Quer ressaltasse as causalidades culturais - atrelando tal ascensão às mobilizações provocadas pela devoção à Reforma da Igreja ${ }^{4}$-, quer insistisse na ruptura política como fator determinante - ao ressaltar a tomada de poder característica de uma Revolução como fator que conferiu sentido histórico a este momento ${ }^{5}$-, a historiografia fez destas expressões dois itinerários para o mesmo destino: o contexto do estabelecimento da hegemonia pontifícia sobre o Ocidente $^{6}$.

FLICHE, Augustin. La Réforme Grégorienne. Louvain: Spicilegium S. Lovaniense, 3 vol, 1924-1937, 3 vol. ; TELLENBACH, Gerd. Church, State and Christian Society at the time of the Investiture Contest. Nova York: Harper Torchbooks, 1959; MORGHEN, Raphaello. Medioevo Christiano. Bari: Editori Laterza, 1962; FORNASARI, Giuseppe. Medioevo Riformato del Secolo XI: Pier Damiani e Gregorio VII. Nápoles: Liguori Editore, 1996; FOULON, Jean-Hervé. Église et Réforme au Moyen Âge. Bruxelles: De Boeck, 2008.

CANTOR, Norman. Church, Kingship and Lay Investiture in England (1089-1135). Princeton: Princeton University Press, 1958; LEYSER, Karl. Comunications and Power in Medieval Europe: the gregorian revolution and beyond. Londres: Continuum International Publishing Group, 1994; CANTARELLA, Glauco. II Sole e la Luna: la rivoluzione di Gregorio VII papa, 1073-1085. Roma: Editori Laterza, 2005; CUSHING, Kathleen. Reform and the Papacy in the Eleventh Century: spirituality and social change. Manchester; Nova York: Manchester University Press, 2005.

Embora concordemos com a conclusão que aponta os séculos XI e XII como era da ascensão política do papado no conjunto da sociedade ocidental, discordamos das propostas que explicam esta ascensão como uma "Reforma" tanto quanto como uma "Revolução". Pois ambos conformam a historicidade medieval a dois modelos ideológicos claramente extemporâneos: a noção de "Reforma" à doutrina social católica de 1890 a 1960; o conceito de "Revolução" à filosofia política franco-alemã de 1770-1830. Sobre tais críticas ver o restante deste texto e, para uma apresentação sistemática: RUST, Leandro Duarte. Colunas de São Pedro: a política papal na Idade Média Central. São Paulo: Annablume, 2011. 
Os "antipapas", portanto, povoaram este turning point da sociedade ocidental. Seu aparecimento está presente em quase todos os capítulos históricos destacados pelos autores quando se trata de explicar a "Reforma" ou a "Revolução Papal". O envolvimento da Corte Imperial na tripla deposição de Bento XI, Silvestre III e Gregório VI no ano de 1046, por exemplo, é tema recorrente nos debates sobre a "crise entre Estado e Igreja": a destituição teria sido, paradoxalmente, um marco de declínio das realezas sacralizadas. Dali em diante elas perderiam terreno para a teocracia papal que floresceria na nova Roma, reestruturada após aquele desastre. Mas as monarquias revidariam. Décadas depois, elas encontrariam a saída para sua afirmação política e jurisdicional ao reescreverem a origem e a natureza dos poderes do rei, apresentando-o como detentor de uma indivisível "soberania secularizada". A intervenção imperial fez mais do que colocar o papado em ordem. Ela proporcionou um recomeço, inaugurou uma nova fase ao dar origem à longa sucessão de pontífices que se autoproclamavam os detentores de todos os poderes conhecidos, espirituais ou temporais. Suas pretensões universais encurralaram as prerrogativas régias, empurrando os monarcas para a difícil tarefa de justificar sua autoridade e impedir que suas vozes naufragassem na condição de poderes subalternos, de meros "braços seculares" do sacerdotium. ${ }^{7}$

As sangrentas guerras movidas por Honório II entre os anos de 1061 e 1063 teriam estremecido a legitimidade papal de tal modo que, no esforço para restaurá-la, a Cúria romana buscou como nunca antes o amparo das leis escritas. Entretanto, o que se seguiu foi algo muito maior do que uma recomposição de autoridade. Os historiadores asseguram que o empenho foi o ponto de partida de uma interminável multiplicação de compilações textuais e de criação de uma racionalidade jurídica que fizeram do papado a vanguarda na produção do direito canônico, assegurando seu lugar de fundador das tradições legislativas europeias: "fundamental changes that began to sweep through (...) the Christendom in the closing decades of the 11th century radically transformed the laws and legal

7 A bibliografia sobre o tema em questão é gigantesca. Nos limitaremos aqui - sobretudo a título ilustrativo - a indicar as referências mais conhecidas que sustentam a tese descrita acima em suas linhas gerais: PACAUT, Marcel. La Théocratie: l'Église et le pouvoir au Moyen Age. Paris: Aubier, 1957; ULLMANN, Walter. Medieval Papalism. Londres: Methuen, 1949; Principles of Government and Politics in the Middle Ages. Londres: Methuen, 1961; WILKS, Michael J. . The Problem of Sovereignty in the Later Middle Ages. Cambirdge: Cambridge University Press, 1963; CAMERON, James Munro. Images of Authority: a consideration of the concepts of Regnum and Sacerdotium. Londres: Burns \& Oates, 1966; TIERNEY, Brian. The Crisis of Church and State. Toronto: University of Toronto Press, 1988; CANNING, Joseph. A History of Medieval Political Thought (300-1450). Nova York: Routledge, 1996; MULDOON, James. Empire and Order. the concept of Empire (800-1800). Nova York: Palgrave Macmillan, 1999; MELVE, Leidulf. Inventing the Public Sphere: the public debate during the investiture contest (c.1030-1122). Leiden: Brill, 2 vol., 2007. 
practices [...]. Within the following century-and-a-half, a new legal culture emerged in the West". ${ }^{8}$ As epístolas e os escritos pontifícios - muitos deles nascidos como retaliação às "ambições dos falsos papas" - assumiram papel central na nova cultura legal. ${ }^{9}$

Ao longo de sua trajetória eclesiástica, entre as décadas de 1050 e 1060, o antipapa Clemente III esteve presente nos cenários em que cresceram as mobilizações coletivas e as espirais de conflitos sociais justificados pelo cumprimento clerical dos ideais de disciplina pastoral, obediência hierárquica e rigor moral, venerados como formas de imitação da vida apostólica. ${ }^{10}$ As peregrinações de Gregório VIII até Jerusalém, no limiar do século XII, lembravam a devoção atribuída às multidões de cruzados, cuja "mentalidade de conquista" é apontada por muitos como a mola propulsora da chamada expansão feudal. ${ }^{11} \mathrm{O}$ patronato de igrejas e monastérios encorajado por Anacleto II nos anos de 1110 a 1129 - e mantido pelas generosas doações materiais de sua poderosa família de judeus romanos convertidos exemplificava os processos de fixação patrimonial da identidade religiosa destacados em recentes estudos: processos que produziram uma inédita "espacialização do sagrado", estruturando formas de dominação social que se estenderiam até o século XVIII. ${ }^{12}$

BRUNDAGE, James. The Medieval Origins of Legal Profession: canonists, civilians and Courts. Chicago: Chicago University Press, 2006, p. 75.

BERMAN, Harold. Law and Revolution: the formation of western legal tradition. Cambridge: Harvard University Press, 1984; CUSHING, Kathleen. Papacy and Law in the Gregorian Revolution: the canonistic work of Anselm of Lucca. Oxford: Oxford University Press, 1998; SWEENEY, James \& CHODOROW, Stanley (Ed.). Popes, Teachers and Canon Law in the Middle Ages. Ithaca: Cornell University Press, 1989; PRODI, Paolo. Uma História da Justiça. São Paulo: Martins Fontes, 2005; WITTE JR., John \& ALEXANDER, Frank S. (Ed.). Christianity and Law: an introduction. Cambridge: Cambridge University Press, 2008; WITTE, John. God's Joust, God's Justice: Law and Religion in the Western Tradition. Grand Rapids: Wm. B. Eerdmans Publishing, 2006.

LAMBERT, Malcolm. Medieval Heresy: popular movements from the Gregorian Reform to the Reformation. Oxford : Blackwell, 1977; BRUNDAGE, James A. Law, Sex, and Christian Society in Medieval Europe. Chicago: The University of Chicago Press, 1987; CHÉLINI, Jean. Histoire Religieuse de l'Occident Médiéval. Paris: Hachette, 1991; VAUCHEZ, André, A Espiritualidade na Idade Média Ocidental. Rio de Janeiro: Zahar, 1995; BARSTOW, Anne Llewellyn. Married Priests and the Reforming Papacy: the eleventh century debates. Nova York-Toronto: The Edwin Mellen Press, 1982; MILLER, Maureen Catherine. Power and the Holy in the Age of the Investiture Conflict. a brief history with documents. Boston: Bedford \& Saint Martin's, 2005.

COWDREY, Herbert Edward John. Popes, Monks, and Crusaders. Londres: Hambledon, 1984; RAMOS, Luís Garcia-Guijarro. Papado, Cruzadas Y Ordenes Militares, siglos XI-XIII. Madri: Cátedra, 1995; RILEY-SMITH, Jonathan. The First Crusade and the Idea of Crusading. Londres: Continuum, 2003. 2006; LAUWERS, Michel. Naissance du Cimetière: lieux sacrés et terre des morts dans l'occident medieval. Paris: Aubier, 2005. Ver ainda: STROLL, Mary. Symbols As Power: The Papacy Following the Investiture Contest. Leiden: Brill, 1991. 
Em síntese, as décadas compreendidas entre 1040 e 1140, nas quais o historiador inglês Robert I. Moore viu eclodir a "primeira revolução europeia" ${ }^{13}$ formam, igualmente, um século de "Antipapas".

\section{Desmascarar o Passado}

Ao pousarem os olhos sobre os registros destas décadas fulcrais, os historiadores se deparam com uma intrigante repetição de "falsos pontífices". Uma crônica após a outra, de epístola em epístola, os estudiosos avançam por épocas documentais reencontrando sem cessar as alusões àqueles personagens, cujas sombras reaparecem toda vez que tentamos projetar alguma luz sobre os séculos XI e XII. Como resultado, sua imagem simplesmente recheia os escritos dedicados não somente à história dos papas, mas à própria História Medieval, especialmente as páginas escritas desde os tempos oitocentistas.

Por certo, não devemos exagerar. Trata-se de uma atenção emprestada, de segunda mão. Pois as razões da relevância histórica alcançada por aqueles personagens não estavam em suas próprias biografias; suas ações careciam de grandeza genuína e foram importantes apenas na medida em que cruzaram destinos alheios - ao menos era isso que sugeriam as publicações do século XIX. Os "antipapas" precisavam ser conhecidos apenas o suficiente para explicar sua participação em certos desalinhos na correta ordem da política papal: se esta tivesse sido poupada das disputas internas provocadas por aqueles eclesiásticos, eles, provavelmente, figurariam no rodapé da História. Eruditos como J. J. Ignaz von Döllinge ensinavam a seus incontáveis leitores dos anos 1840 que clérigos como Clemente III, rival de Gregório VII, eram homens a serem lembrados apenas pela façanha de suas campanhas pelo governo apostólico terem atravessado a atuação de um pontífice legítimo. ${ }^{14}$ Ponto de vista amplamente partilhado por John Miley, pioneiro no estudo dos Estados Papais. ${ }^{15}$

13 MOORE, Robert lan. The First European Revolution (970-1215). Oxford: Blacwell, 2000.

14 Eis um trecho emblemático da perspectiva do célebre reverendo alemão: "It was not long before Henry again appeared in Italy; and whilst Gregory, in a Roman synod, repeated the sentence of excommunication against him, he caused Guibert to be recognized as pope in an assembly of Lombard bishops, in the year 1081, although the whole Christian world was in communion with Gregory". In: DÖLLINGER, Johann Joseph Ignaz von. History of the Church. Londres: C. Dolman, 1841, vol. 3, p. 310.

15 MILEY, John. The History of the Papal States: from their origin to the present day. Londres: T. C. Newby, 1850 , vol. 2, p. 351-639. 
Dedicar-Ihes um livro inteiro era algo impensado. Entretanto, ainda assim, o lugar ocupado por eles não poderia ser visto como insignificante, nem mesmo negligenciável. O papel desempenhado pelos "antipapas" constituía o sentido do devir histórico. Perdê-los de vista na compreensão do passado significava ser incapaz de seguir o longo encadeamento de razões que definiu o presente como o vivemos ainda hoje. Mesmo sob uma irredutível reputação de coadjuvantes, a imagem daqueles "usurpadores" surge na escrita da História com contornos fortes. Acima de tudo, eles eram necessários para colocar em evidência a excepcionalidade e a centralidade da fé reformadora dos pontífices medievais. Ainda que dispersa e orientada por acepções epistemológicas conflitantes, a historiografia do século XIX concordava em caracterizar todos aqueles improváveis pretendentes ao trono de Pedro de um mesmo modo: como perfeitos contrastes religiosos de seus antagonistas.

Todos os antipapas surgiam como a mesma massa de transgressores incorrigíveis, cujas falhas eram retratadas como imenso pano de fundo sombrio sobre o qual reluziam as virtudes dos pontífices considerados legítimos. Generalizadas, as diferenças entre os dois grupos formavam um claro-escuro essencial. Com isso, um imenso espectro de biografias diversas e atuações políticas distintas, muitas das quais distanciadas no tempo por décadas, foram reduzidas a uma mesma e monótona razão, orientadas para contar sempre a mesma história e ensinar a lição sobre como as razões do bom governante tinham um brilho raro, cintilando a condição de única força capaz de vencer as torrentes de ambição e incidentes pessoais que inundam a vida em sociedade. Vejamos um exemplo representativo desta característica: o episódio envolvendo Cádalo, bispo de Parma ("antipapa" Honório II), e Anselmo, bispo de Lucca (papa Alexandre II), adversários na sucessão papal de 1061.

Comecemos por dois autores que marcaram épocas. Fiel às ideias formuladas por Ludovico Muratori em meados do século XVIII, Gaetano Moroni preservou em seu ilustre Dizionario di Erudizione Storico-ecclesiastica a imagem de Alexandre como o incansável combatente dos vícios clericais e arbitrariedades laicas que assolavam a sociedade de seu tempo. Dificilmente poderia ser de outro modo, pois reverenciar Muratori - poeta e erudito que compusera as gigantescas coleções Rerum Italicarum Scriptores e Antiquitates Italicae Medii Aevi - era prova de boa formação e sinal de maturidade intelectual para as gerações de historiadores europeus formados desde muito antes da Revolução Francesa. ${ }^{16}$ Muratori havia reputado o bispo de Lucca como prelado tão zeloso e 
comprometido com a disciplina clerical quanto o heróico Gregório VII. Essa personalidade teria empurrado Anselmo para uma luta sem descanso contra os abusos e as injustiças que o rodeavam. ${ }^{17}$

O eminente medievalista do lluminismo assegurou, portanto, que o bispo de Lucca foi reconhecido ainda em vida como rara figura, um dos poucos prelados verdadeiramente empenhados em favor do equilíbrio social numa época desordenada pela anarquia feudal: era preciso valorizar suas ideais e, sobretudo, perpetuar a memória de seu heroísmo. Foi o que fez Moroni. Era "evidente" - ele assegurou - que a ascensão de Anselmo à Santa Sé decorria deste inconfundível prestígio, de uma ânsia partilhada por muitos de ver coroado aquele impecável engajamento pela boa ordem da societas christiana. Portanto, sua eleição não poderia ser vista de outro modo que não fosse o de um ato moralmente superior, isento de quaisquer irregularidades religiosas e canônicas, resultando do “unanime consenso de' sacri Eletori". As acusações de simonia disparadas contra ele - e que correram de boca em boca, como ficaria evidente no Concílio de Mântua, nos idos de $1064^{18}$ - não passavam de uma campanha de difamação "da Cadaloo suo avversario fierissimo". ${ }^{19}$

Quanto a Cádalo, por sinal, os oitocentistas pareciam não ter dúvida: sua vileza ao levantar falsas acusações contra o rival era o mais brando de todos seus disparates. Basta relembrar a descrição oferecida pelo visconde Louis-Marie de Lahaye Cormenin, em 1846: o bispo de Parma, "whom several chroniclers designate by the name of anti-pope, was a concubinary, and had already been condemned for the crimes of extortion and adultery in the councils of Pavia, Mantua, and Milan". ${ }^{20}$ É impossível saber ao certo, mas é provável, pela narrativa e pelas indicações dispostas no restante do texto, que os "diversos cronistas" em que se fundamentava Cormenin fossem apenas dois nomes: 0 cardeal Pedro Damião ${ }^{21}$ e Bonizo, bispo de Sutri. ${ }^{22}$ Ambos pessoalmente comprometidos com a causa

17 MURATORI, Ludovico Antonio. Dissertazioni sopra le Antichità Italiane. Milão: Società Tipografica de' Classici Italiani, 1837, vol. 5, p, 189.

18 ANNALES ALTAHENSIS MAIORES. MGH, SS. Rer. Germ., 2: 65; LAMBERTO DE HERSFELD. Annales. MGH SS. 5: 167-168; JAFFÉ, Philippus; LOWENFELD, S. et alii (Ed.). Regesta Pontificum Romanorum. Leipzig: Veit, 18851888, p. 392; HEFELE, Charles Joseph \& LECLERCQ, Henry. Histoire des Conciles aprés les documents originaux. Paris : Letouzey et Ané, 1912-1915, 4: 2, p. 1240-1249.

19 MORONI, Gaetano. Dizionario di Erudizione Storico-ecclesiastica da S. Pietro sino ai nostri giorni. Veneza: Tipografia Emiliana, 1840, vol. 1, p. 230.

20 CORMENIN, Louis-Marie de Lahaye. The Public and Private History of the Popes of Rome. Londres: J. Campbell, 1846, p. 357.

21 PEDRO DAMIÃO. Die Briefe. MGH Epp. Kaiserzeit, Briefe, tomo IV, n. 154 e 156; PEDRO DAMIÃO. Disceptatio Synodalis Inter Regis Advocatum et Romanae Ecclesiae Defensorem. PL, v. 145, col 67-87. 
de Alexandre II e a necessidade de assegurar a legitimidade de seus partidários. O primeiro pertencia ao círculo de poderosos que elegeu Anselmo e estava pessoalmente implicado na defesa da aceitação do novo eleito. Damião partiu para a ofensiva contra Cádalo, a quem chamava de "filho de Belial, agitador das trevas": suas cartas e seus escritos foram armas empunhadas na implacável guerra de propaganda travada com os partidários do bispo de Parma. Tomá-lo como respaldo suficiente é renderse inteiramente aos seus interesses políticos. Quanto ao segundo cronista, basta dizer, como fez Reginald Poole nos idos de 1917, que "Bonizo was quite without scruple in falsifying facts which did not suit his opinions". ${ }^{23}$

Tal imagem não tem plausibilidade histórica. Cádalo vivenciou plenamente 0 ideal de Renovatio da Igreja. Escolhido pessoalmente pelo imperador Conrado II para chanceler da Sicília; ele foi ainda vicedominus de Verona; bispo eleito de Parma em 1045; fundador do monastério de São Giorgio in Braida; benfeitor de igrejas; homem de confiança do rei germânico Henrique III. O "antipapa" era uma notória liderança reformadora no interior da península itálica, como demonstraram pesquisas posteriores a Moroni. ${ }^{24}$ Se a historiografia oitocentista desconheceu isto não foi devido a restrições documentais ou à inabilidade crítica. Mas, porque a imagem do antagonista de Alexandre II devia servir à validação de um modelo intelectual profundamente enraizado na percepção de mundo dos historiadores: narrar as transformações do passado como evidências de um irrefreável progresso ético.

Descrever a política de outrora como uma arena de opostos morais era - conforme a experiência daqueles homens da primeira grande Era Industrial - desvendar a grande trama pela qual o desenvolvimento humano necessariamente se colocava em movimento. Aquela caracterização dualista projetada sobre Cádalo e Anselmo incorporava o século XI como episódio de uma dinâmica ética maior, universal, na qual os leitores poderiam reconhecer algo de uma marcha moral que dizia respeito a toda Humanidade, e que estava longe de ser um episódio isolado, apenas mais uma querela qualquer, perdida nas brumas de memórias ancestrais. Estudá-los faria sentido desde que fosse

BONIZO DE SUTRI. Liber Ad Amicum. MGH Ldl, tomo I, p. 595-600.

POOLE, Reginald L. ."Benedict IX and Gregory VI", The Proceedings of the British Academy, 1917, vol. VIII, p. 12.

CENCI, Pio. Documenti inediti su la famiglia e la giovinezza dell'Antipapa Cadalo. Archivio Storico per le Province Parmensi, n. 23, 1923, p. 185-223; n. 24, 1924, p. 309-344; CAVALLARI, Vittorio. Cadalo e egli Erzoni. Studi Storici Veronensi, n. 15, 1965, p. 59-170; CAPITANI, Ovidio. Immunità Vescovili ed Ecclesiologia in età "Pregregoriana" e "Gregoriana". Spoleto: Centro Italiano di Studi Sulla'Alto Medioevo, 1966, p. 62-139; CASTAGNETTI, Andrea. Fra I Vassalli: marchesi, conti, 'capitanei', cittadini e ruralli dalla documentazione del capitolo della cattedrale di Verona (século X-metá XII). Verona: Libreria Universitaria, 1999; MILLER, Maureen. The Bishop's Palace: architeture and authority in Medieval Italy. Ithaca: Cornell University Press, 2000, p. 86-121; MILLER, Maureen. The Formation of a Medieval Church: ecclesiastical change in Verona (950-1150). Ithaca: Cornell University Press, 1993, p. 73-77. 
possível enxergá-los como personagens de um capítulo de uma grande Filosofia da História, decifrada com a ajuda dos "papas" e "antipapas". Prossigamos como nossa análise desta perspectiva oitocentista.

Pontífices e "Falsos Pontíices" formavam os lados opostos de um conflito vital, em tudo providencial. Seu enfrentamento permitia entrever a ação de uma poderosa força que despertava nos homens e mulheres medievais o desejo de transformar o mundo. Os riscos oferecidos pela possibilidade de triunfo dos "antipapas" quebravam a inércia das escolhas, a omissão das condutas. Ainda que remotas, suas chances de vitória faziam soar as sirenes do envolvimento político. Cada uma das disputas, ocorridas entre 1040 e 1140, afetava profundamente os agentes históricos, rompendo os diques que continham o mais poderoso ímpeto coletivo de transformação do mundo de então, liberando a potência que provocava as consciências para a urgência de corrigir as falhas, endireitar os costumes, separar o certo do errado e zelar pelo justo: a espiritualidade devotada a reformar a igreja e os fiéis.

O ideal de purificação do convívio cristão figurava na historiografia oitocentista como a razão capaz de despertar as preocupações e mobilizar as energias dos que viveram na "Idade da Fé" - fama amplamente atribuída à Idade Média. A religiosidade era encarada como o que provocava a ruptura, a mudança, aquilo que nos tempos medievais redefinia os limites cabíveis à consciência e ao agir. Ela era o que os autores enxergavam como a causa da descontinuidade e, ainda que inconscientemente, exaltada como a força especificamente medieval de superação dos entraves ao estabelecimento de uma ordem social mais coesa e normatizada. Enfim, a fé reformadora era conceituada como um motor da evolução das relações sociais. Todavia, esta fé era narrada como um arrebatamento tão poderoso quanto excepcional: a sociedade da época estava atada ao mundano. A maioria dos que viveram naqueles tempos estavam amarrados aos grilhões da arbitrariedade feudal, acostumados ao arcaísmo parasitário das elites nobiliárquicas. Aparentemente abstratos demais, genéricos em excesso, tais aspectos ganhavam vida precisamente nas personalidades dos "antipapas", figuras tratadas como amostras humanas dos obstáculos a serem superados pelo progresso ético maior. Mais do que serem descobertos em sua complexidade, eles tinham um papel intelectual a cumprir, isto é, permitir aos historiadores reconhecer a medida da resistência coletiva à mudança para um novo tempo.

Com os "falsos pontífices" os eruditos oitocentistas da História buscavam dotar de carne e osso certos postulados abstratos. Aqueles homens emprestariam forma humana às tendências coletivas de continuidade histórica. Neles estaria encarnada toda a resistência oferecida pela antítese dos tempos. O contraste entre "papas" e "antipapas" humanizava o coeficiente da mudança: eles, necessariamente, deveriam personificar opostos éticos. Pois as diferenças morais que os distanciavam não seriam apenas particularidades pessoais, mas duas categorias do progresso histórico. A vitória daqueles permitia testemunhar o "espírito do tempo" superando as adversidades mundanas - estampadas no 
fracasso destes últimos. Os dois grupos funcionavam como arquétipos, como indicadores de saltos de humanidade. Os "antipapas" personificavam um modo de vida condenado, que deveria ficar para trás na marcha da condição humana, ultrapassado como passado, substituído por um tempo novo, anunciado, instaurado e encarnado no heroísmo reformador dos papas legítimos.

Quando os colocavam lado a lado em suas narrativas, os autores do século XIX compunham metáforas dos avanços realizados pelo Ocidente no tempo, permitindo a seus leitores ver em forma de homens os pontos de partida e de chegada da vida coletiva. A luta pelo poder explicava a História como "teorema do progresso". ${ }^{25} \mathrm{O}$ procedimento textual aparenta notável semelhança com 0 pensamento hegeliano e o propósito de encontrar uma unidade moral universal escondida atrás da multiplicidade contingente dos particulares. ${ }^{26}$ Sob a diversidade de origens, formações e momentos vivenciados pelos "antipapas" havia um idêntico comum: todos foram o "não-ser" moral dos papas, seu correlato dialético. Por isso não importava o que cada um deles tinha protagonizado em vida, todos não passaram de vencidos, do lado derrotado e superado pela força ética. Por isso era preciso naturalizar a memória daqueles eclesiásticos como contrários vivos do progresso histórico. E ninguém exemplificou melhor esta orientação historiográfica do que Clemente III.

Escrevendo no calor revolucionário de 1830, Abel François Villemain deu vida ao argumento com uma clareza meridiana: em 1080, sob o coro de vozes clericais instruídas pelo imperador, o arcebispo Guiberto de Ravenna foi aclamado para assumir o governo da Santa Sé porque era, "depuis longtemps, ennemi de Gregoire VII", seu "rival naturel" e o "complice présumé" de pavorosos atentados contra a vida do pontífice. Era, em suma, o homem certo para levar às últimas consequências o ódio comum nutrido contra aquele que se sentava na cátedra de Pedro. ${ }^{27} \mathrm{Na}$ leitura do monumental "Hildebrand als Papst Gregor VII. und sein Zeitalter" é quase possível sentir o gosto amargo das palavras que Johannes Voigt usou para retratar o arcebispo: um pobre diabo escravizado pela ambição, culpado de toda sorte de crimes. ${ }^{28}$ Segundo o Barão Henrion, jornalista conhecidíssimo dos anos 1830 ,

25 HÖSLE, Vittorio. O Sistema Hegel: o idealismo da subjetividade e o problema da intersubjetividade. São Paulo: Loyola, 2007, p, 41-60; RORTY, Richard. Truth and Progress: philosophical papers. Cambridge: Cambridge University Press, 1998, p. 247-303. Sobre a compreensão hegeliana do progresso-como-poder, ver: DUPAS, Gilberto. O Mito do Progresso ou o Progresso como ideologia. São Paulo: Editora UNESP, 2006, p. 41-55.

26 Acessado através da prestigiada tradução de H. B Nisbet: HEGEL, Georg Wilhelm Friedrich. Lectures on the Philosophy of World History. Cambridge: Cambridge University Press, 1975, p. 30.

27 VILLEMAIN, Abel François. Histoire de Grégoire VII precedé d'un discours sur l'Histoire de la Papauté. Paris: Librarie Académique, 1835, vol. 2, p. 275.

28 Acessado através da edição francesa: VOIGT, Johannes. Histoire du Pape Grégoire VII et de son siècle: d'aprés les monuments originaux. Paris: A. Vaton Editeur, 1838, vol. 2, especialmente as páginas 300 e 301. 
a índole criminosa de Clemente não deixava margem para dúvidas, pois "par les soins de Clément le schisme de Cadalous avait été organize, [...] il avait obtenu l'archevêché de Ravenne pour prix des ses complaisancés, et qu'on avait excommunié comme spoliateur de son Église". ${ }^{29}$

John W. Bowden, ${ }^{30}$ August F. Gfrörer, ${ }^{31}$ Odon Delarc, ${ }^{32}$ Gerold Ludwig Meyer von Knonau, ${ }^{33}$ Arnold Harris Matthew, ${ }^{34}$ E. Wilmot Buxton ${ }^{35}$ : da escrita de todos estes autores sobressaía um Clemente arrivista, traiçoeiro, fraco, vilão. Embora fossem conhecidas as evidências documentais de sua rigidez reformadora, do combate contra o clero simoníaco, de sua intolerância a qualquer violação do celibato e até mesmo sua reputação de santo já no século $\mathrm{XI}^{36}$ a historiografia retratava-o à feição de exigências conceituais idênticas às da filosofia hegeliana da História. Quer surgisse caracterizado como um gênio maléfico ou uma marionete dos interesses imperiais, o "antipapa" era valorizado pelo que supostamente lhe faltava; isto é, pela ausência das virtudes e da fibra moral que abundavam no espírito de Gregório VII, sempre "obstinate in his adherence to logical consequences, immoveable in his

HENRION, Mathieu-Richard-Auguste. Histoire des Papes depuis Saint Pierre jusqu'à Grégoire XVI. Bruxelas: Société Nationale, 1838, vol.1, p. 245.

BOWDEN, John William. The Life and Pontificate of Gregory the Seventh. Londres: J. G. F. \& J. Rivington, 1840. GFRÖRER, August Friedrich. Pabst Gregorius VII und sein Zeitalter. Leipzig: Schaffhausen, 1803-1861, 10 vol. DELARC, Odon. Saint Grégoire VII et la réforme de l'église au XIe siécle. Paris: Retaux-Bray, 1889, vol. 3.

MEYER VON KNONAU, Gerold Ludwig. Jahrbücher des Deutschen Reiches unter Heinrich IV. und Heinrich V. Leipzig: Duncker \& Humblot, 1890-1909, sobretudo o vol. 2. RAVENNA, Epistolae et Privilegia. PL, 1882, tomo 148, col. 827-842; JAFFÉ, P. et alii (Ed.). Regesta Pontificum Romanorum. Leipzig: Veit, 1885, tomo I, n. 5314-5341. É vital registrar que, desde o século XIX, eram conhecidos os registros da participação do arcebispo do concílio romano de 1061, no qual aprovou e subscreveu o Decretum Adversus Simoniacos e a In Nomine Domini, ver: BONIZO DE SUTRI, Liber Ad Amicum. MGH, Ldl, 1891, tomo I, p. 592-594; JAFFÉ, P. et alii, op. cit., 1885, tomo I, n. 4392-4398; MANSI, Giovanni D. . Sacrorum Conciliorum nova et amplissima collectio. Veneza, 1758-1798, tomo XIX, col. 885-886; WATTERICH, J. M. (Ed.). Pontificum Romanorum Vitae. Leipzig:Guilhelmi Engelmani, 1860-1862, tomo I, 229-232; HEFELE, Ch. J. \& LECLERCQ, H.. Histoire des Conciles aprés les documents originaux. Paris : Letouzey et Ané, 1912-1915, tomo IV, p. 1133-1137. Sobre a santidade do "antipapa": CODEX ULDARICI. In: JAFFÉ, P. (Ed.). Monumenta Bambergensia. Berlim: 1869, p. 194; RUSCONI, R. II papa santo negli ultimi secoli del medioevo: tra Gregorio VII e Urbano V. In: MELVILLE, G. et alii (Ed.). Institution und Charisma. Köln: Boehlau, 2009, p. 485. Por fim, sobre o enquadramento historiográfico do arcebispo à luz de uma notória exaltação da figura de Gregório VII ver: FALCONIERI, Tommaso di Carpegina. "Popes through the looking glass or 'Ceci n'est pas un pape'". Reti Medievali Rivista, vol. 13, n. 1, 2012, p. 121-136; SPRENGER, Kai-Michael. "The Tiara in the Tiber. An Essay on the damnatio in memoria of Clement III (1084-1100) and Rome's River as a Place of Oblivion and Memory". Reti Medievali Rivista, vol. 13, n. 1, 2012, p. 153-74. 
purposes", conforme as palavras de ninguém menos que Leopold von Ranke. ${ }^{37} \mathrm{~A}$ reputação oitocentista de Clemente foi resumida com primor por Ferdinand Gregorovius, o grande maestro dos estudos sobre a Itália Medieval e Renascentista realizados após 1860. Eis sua descrição do arcebispo:

So ancient an enemy, and one so intimately versed in all political affairs as Wibert, must necessarily appear as anti-pope on the scene of action. He was more dangerous than Cadalus could be. Distinguished by illustrious birth, learning, and statesman-like insights, he had long aimed in his ambition at the tiara, which he hope to wrest from Gregory; he had now the title of pope, but must perforce obtain consecration and power from distant S. Peter. ${ }^{38}$ (Os grifos são nossos).

Gregório representava o rigor moral, Clemente o oportunismo político. O papa era a personificação da retidão do espírito e da constância da razão; o "antipapa" da volubilidade de caráter e das desilusões provocadas pela cupidez. 0 embate entre eles era o movimento vivo de um processo civilizador almejado por tantos escritores do Oitocentos. Orientado pela racionalidade e para a liberdade, o autocontrole do primeiro colidia com a hostilidade das obstinações emocionais do segundo. ${ }^{39}$

Por isso, o "antipapa" jamais triunfaria. Seu ingresso em Roma, forçado pelo fio das espadas imperiais, sua entronização na cátedra de Pedro, o humilhante exílio imposto a Gregório VII, a desorientação que tomou conta dos gregorianos após a melancólica morte de seu líder em Salerno, nada disso significava êxito histórico. Pois, segundo os autores do século XIX, o sentido da vida em sociedade era moral, não material, tampouco político. A integridade ética do velho pontífice era a verdadeira e única força motriz da História. Dela dependia o modo de vida dos homens e mulheres que viriam depois. Sem ela as conquistas temporais tornavam-se vitórias ocas, vãs; tão desprovidas de significado quanto vantagens efêmeras e quebradiças. A lição tem fortes colorações hegelianas. Por mais fragorosos que fossem os sucessos antipapais, seus êxitos eram realizações temporais, matérias perecíveis, regidas pela finitude. Já a integridade ética que os pontífices mantinham inquebrantável em seus corações era, por outro lado, um dom do espírito, sublime, ideal, permanente: como o Absoluto

37 RANKE, Leopold von. History of the Popes of Rome, their Church and State. Londres: Henry G. Bohn, 1847, vol. 1, p. 20.

38 GREGOROVIUS, Ferdinand. History of Rome in the Middle Ages. Londres: George Bell \& Sons, 1986, vol. 4, pt. 1, p. 221.

39 Ver, por exemplo: HEY, Richard. Some Principles of Civilization. Cambridge: Cambridge University Press, 1815; MAYBEL, Stephen. Civilization Civilized or The Process of Nationalization. Londres: Lovell, Gestefeld \& Company, 1892. 
exaltado pelo autor de Fenomenologia do Espírito. ${ }^{40} \mathrm{~A}$ dialética entre ser e não-ser realizou-se, historicamente, como o embate entre papas e "antipapas".

Mesmo naufragando na derrocada material, e tendo deixado como legado o desastre de uma Roma incendiada e saqueada, Gregório tinha a História ao seu lado:

The tide on which the courageous Pope had hitherto been borne was followed by the ebb of fortune, his long distress in Rome, his fall and his death in exile. But the marvellous genius of the man shines, not at its strongest, but perhaps at its clearest, in the period of decline, until his star sinks, solitary and splendid, below the horizon of history into the sea of time. ${ }^{41}$ (Os grifos são nossos).

A opinião estampada nas palavras de Gregorovius era bastante comum. Basta notar a semelhança que ela conservava com textos então amplamente lidos, como o "L'Église au Moyen Âge: du VIle au Xlle siècle", obra publicada por Jean Baptiste Honoré Raymond Capefigue em 1852. Segundo ele, o significado do governo gregoriano não estava dado em seu desfecho trágico, vivido em meio à expulsão de Roma:

L'Église triompha sous la main de Grégoire VII et par la proclamation de ses belles maximes, qui imprimaient partout l'obéissance. [...] Et ce qu'il faut le plus remarquer dans l'histoire de Grégoire VII, c'est que as vie n'offre qu'um long martyre, une lutte douloureuse, tout entière consacrée à la défense des ces principes sur lequels il ne fait pas la plus petite concession. ${ }^{42}$ (Os grifos são nossos).

Presumidamente realçada por um drástico contraste com a conduta dos "antipapas", a fé reformadora dos pontífices surgia, na historiografia do século XIX, como uma versão medieval da "astúcia da Razão" desvendada por Hegel. ${ }^{43}$ É como se aqueles eclesiásticos, ao perseguirem seus interesses pessoais, arrastados pela ambição desmedida para escolher às cegas, tivessem contribuído para o progresso da racionalidade universal, da qual todos nós - seus herdeiros no tempo - tiramos

40 "For on the one hand, we have in history ingredients and higher determinants which are remote from the conceptual world. On the other hand, we set up against this idea of a higher necessity, an eternal justice and love, the absolute and ultimate end which is truth in and for itself. In contrast to natural being, this second, opposite pole is based on abstract elements, on the freedom and necessity of the concept'. In: HEGEL, Georg Wilhelm Friedrich. Lectures on the Philosophy... op. cit., 1975, p. 26.

GREGOROVIUS, Ferdinand, op. cit., p. 222.

42 CAPEFIGUE, Jean Baptiste Honoré Raymond. L'Église au Moyen Âge: du VIle au XIle siècle. Paris: Amyot, 1852, tomo I, p. 303-304. 
proveito. De alguma maneira enigmática, a forma como eles atropelavam até as coisas santas, incorrendo nas condutas mais reprováveis, não deixava de ser instrumento de realização de grande avanço moral, instigado e fortalecido pela luta, pelo confronto entre paixões e razão motivado pelo prestígio da Sé de Pedro. É o que ensinava o filósofo alemão:

The particular interests of passion cannot therefore be separated from the realization of the universal, for the universal arises out of the particular and determinate and its negation. The particular has its own interests in world history; it is of a finite nature, and as such, it must perish. Particular interests contend with one another, and some are destroyed in the process. But it is from this very conflict and destruction of particular things that the universal emerges, and it remains unscathed itself. For its not the universal Idea which enters into opposition, conflict, and danger; it keeps itself in the background, untouched and unharmed, and $\mathbf{s}$ ends forth the particular interests of passion to fight and wear themselves out in its stead. ${ }^{44}$ (Os grifos são nossos)

Os "antipapas" eram diferentes máscaras que escondiam o verdadeiro rosto do real. Era preciso desmascará-los para reconhecer a identidade única do passado. Ao descrevê-los a historiografia estava aparentemente orientada, de modo tácito - quiçá imperceptível - por uma pergunta fundadora: "a que contribuíram todos aqueles indivíduos historicamente unidos pela ambição de conquista o Trono de Pedro?". Os autores oitocentistas pareciam compartilhar a mesma recusa hegeliana em admitir que o significado das ações e paixões daqueles malfadados prelados medievais esgotava-se em propósitos particulares, motivos circunstanciais. ${ }^{45}$ Embalado por este vigor filosófico, 0 medievalismo ingressaria no século XX instruído por uma certeza seminal: ainda que a documentação a insinuasse confusa ou complexa, a variedade dos "antipapas" escondia a unidade do progresso moral e político do poder pontifício. Progresso ininterruptamente ascendente.

\section{A llegitimidade Presumida}

Um dos mais importantes princípios da filosofia política hegeliana consistia na definição do Estado como a consumação da unidade ética da realidade histórica. Isso quer dizer que na

$44 \quad$ Idem, p. 89.

45 "A miséria revela a finitude e, portanto, a contingência do direito assim como do bem-estar. Noutros termos: a existência de uma pessoa particular e o domínio da vontade particular sem a universalidade do direito não são necessários. [...] Nesta ideia, nenhum valor para si tem o bem-estar como existência da vontade particular: só o possui como bem-estar universal em si, isto é, segundo a liberdade. O bem-estar não é um bem sem o direito. Do mesmo modo, o direito não é o Bem sem utilidade." HEGEL, Georg Wilhelm Friederich. Princípios da Filosofia do Direito. São Paulo: Martins Fontes, 1997, p. 112-115. 
organização da esfera estatal os historiadores encontrariam sempre o ápice da racionalização das condutas e valores coletivos de uma época. ${ }^{46} \mathrm{~A}$ ideia, provavelmente, é familiar aos medievalistas, sobretudo aos leitores de Ernst Hartwig Kantorowicz: esta é precisamente a tese que perpassa cada uma das brilhantes páginas de "Os Dois Corpos do Rei: um estudo sobre teologia política medieval". As grandes transformações nas maneiras de tomar consciência acerca da ontologia, do tempo ou da irredutibilidade deste mundo deságuam nos domínios governamentais, onde alcançam a plena inteligibilidade e abarcam o conjunto das relações sociais. ${ }^{47}$

Este princípio axial espalhou-se pela historiografia oitocentista dedicada ao Papado medieval na forma de um bem-sucedido senso comum. Que pode ser assim formulado: a legitimidade precede e instaura o efetivo exercício do poder. O reconhecimento prévio dos valores partilhados por um indivíduo é o próprio ato fundador de um "lugar de autoridade". Somente em função de seu reconhecimento e aceitação como agente de uma racionalidade ética, de uma ideia do Estado, o indivíduo detém o poder e a voz do comando. A diferença entre obedecer a certas decisões e rechaçá-las como arbitrariedade inaceitável decorria da maneira como o pretendente a líder distinguia-se "no mundo moral que é o Estado". ${ }^{48}$

Pré-requisito para reter e exercer o poder, a legitimidade nascia da harmonia entre "a vontade subjetiva e o bem verdadeiro", universal e racional consubstanciado na forma do direito. ${ }^{49} \mathrm{~A}$ realidade objetiva da força política adquire existência pública na unidade de valores, na moralidade que orienta as vontades e os atos pessoais. ${ }^{50}$ Logo, as lutas políticas têm sempre grande densidade moral, uma profundidade espiritual: elas são prolongamentos de movimentos ético conflitantes, sua continuação histórica por outros meios materiais. O difícil entrosamento entre as consciências é a relação originária que instaura o político e o define como um território de submissão ou resistência, de governo ou tirania, liberdade ou privação:

46 Idem, p.216-318. Ver igualmente: ROSENFIELD, Denis (Org.). Estado e Política: a filosofia política de Hegel. Rio de Janeiro: Zahar, 2003, sobretudo as páginas 101-145.

47 KANTOROWICZ, Ernst. Os Dois Corpos do Rei: um estudo sobre teologia política medieval. São Paulo: Cia das Letras, 1998.

48 HEGEL, Georg Wilhelm Friederich. Princípios da Filosofia... op. cit., p. XXX.

$49 \quad$ Idem, p. 122.

50 "O Estado é a realidade em ato da Ideia moral objetiva, o espírito como vontade substancial revelada, clara para si mesma, que se conhece e se pensa, e realiza o que sabe e porque sabe. No costume tem o Estado a sua existência imediata, enquanto o indivíduo obtém a sua liberdade substancial ligando-se ao Estado como à sua essência, como ao fim e ao produto da sua atividade". Idem, p. 216. 
A verdade, diante daquela que se encerra na subjetividade do sentimento e da representação, é o salto enorme que vai do interior para o exterior, da razão envolta na imaginação para a simples realidade. Neste salto está o esforço de toda a história do mundo, a obra em que a humanidade culta ganhou a eficácia e a consciência da existência segundo a razão, da organização política e das leis. ${ }^{51}$ (Os grifos são nossos).

O sucesso e o fracasso políticos têm raízes morais. Os "antipapas" medievais foram transformados em casos exemplares deste postulado. A ideia ganhou feições de "óbvia" ao longo do século XIX e chegou ao XX coroada como uma pacífica tradição historiográfica. Sua lição era clara, "simples constatação objetiva": a conhecida derrota dos "antipapas" na luta pelo controle da Santa Sé decorria de fraquezas éticas, da inadequação de seus valores, de princípios morais distorcidos e reprováveis. Seu insucesso político só poderia expressar uma presumida ilegitimidade hegeliana. Poucos autores expuseram isso de maneira mais clara que Carl Erdmann em seus estudos dedicados a Maurício Burdino, o arcebispo de Braga que em 1118 foi proclamado "papa Gregório VIII" em oposição a Gelásio II.

Educado em Cluny e Limoges, Maurício chegara à Península lbérica como clérigo respeitado. Tornou-se arcediago em Toledo, de onde saiu como bispo eleito de Coimbra, em 1099. Na função episcopal empenhou-se pela imposição da liturgia romana nos altares hispânicos, então consagrados a rituais próprios, conhecidos como "moçárabes". Peregrino da Terra Santa, ele partilhava com mosteiros e igrejas não apenas a devoção pelas relíquias dos santos, mas a própria riqueza, distribuída como doações patrimoniais. O prestígio local elevou-o a arcebispo de Braga no ano de 1111. O constante empenho pelo reconhecimento do status metropolitano de sua igreja forçou-o a manter contatos diretos com o Pascoal II, de quem se tornou homem de confiança e legado pessoal junto ao imperador Henrique V. ${ }^{52}$ Entretanto, ainda assim, Carl Erdmann viu em Burdino um prelado sem ânimo religioso algum, uma criatura fraca, docilmente manipulável, indolente perante a arbitrariedade, cuja "vida careceu de humana grandeza e ideias diretrizes". ${ }^{53} \mathrm{O}$ erudito alemão fez a reputação oitocentista de "antipapa" devorar a vida do arcebispo: tudo o que restou foi uma espécie de carcaça clerical, a

$51 \quad$ Idem, p. 235.

52 BALUZE, Étienne. Vita Mauritii Burdini archiepiscopi Bracarensis, em Miscellanea Historica, Ed. G. D. Mansi, Lucca, 1761, p. 137-148. Ver ainda: DAVID, Pierre. Études Historiques sur la Galice et le Portugal du Vle au XIle siècle. Coimbra: Gráfica Coimbra, 1947, sobretudo a conclusão das pp. 499-500; SCHWAIGER, Georg. "Grégoire VIII". In: LEVILLAIN, Philippe (Ed.). Dictionnaire Historique de la Papauté. Paris: Fayard, 2003, p. 750-751. 
melancólica figura de um homem irremediavelmente inclinado para "o lado do partido mais fraco". ${ }^{54}$ Nada muito diferente do que outros eruditos germânicos viram em Clemente III.

A coloração hegeliana dos argumentos de Erdmann é sensível. São recorrentes os momentos em que ele parecia se empenhar para convencer o leitor de que a causa papal de Burdino estava condenada desde a origem, já que minada por vazios éticos, enfraquecida pela ausência de uma correta vontade do Estado:

A escolha da personalidade para a glória duvidosa de antipapa abona a suposição de que Henrique não se importava muito com o cisma. Decerto, ordenara, um ano antes, a Maurício que o coroasse, mas, no fundo, o imperador considerava-o uma nulidade. Para a implantação dum cisma nas regiões, que lhe interessavam, portanto na Alemanha e na Itália, estava naturalmente inclinado um alemão ou italiano. [...] Maurício, porém, estranho e apátrida, era a pessoa de antemão designada para, mais tarde, no momento oportuno, poder ser lançado à margem sem ruído. ${ }^{55}$ (Os grifos são nossos).

Note, prezado leitor, o impressionante argumento que sustenta este parágrafo: em busca de legitimar (sic!) sua sacrossanta autoridade, o imperador designou bispo de Roma - portanto, para coroá-lo "pela graça de Deus" - um dignitário que ele próprio considerava uma nulidade, aliando-se a alguém naturalmente destinado a arruinar a causa imperial! Ou seja, a ilegitimidade do antipapa era presumida pelo próprio rei Henrique $\mathrm{V}$, supostamente consciente do fato de ter proclamado como "O Vicário de Pedro na terra" um partidário inadequado, inapropriado, um homem a ser varrido para longe da vista de todos. Mas não há razões para ver isso como algo implausível, certo? Afinal, este era o tipo de coisa que o historiador poderia esperar de um monarca que dividiu a Cristandade sem sequer importa-se muito com isso...

As aspirações de Maurício eram reféns de uma desventura hegeliana projetada pelo olhar historiográfico: a pobreza de virtudes era uma sentença política inescapável. Por sua timidez moral ele estava condenado a não despertar a obediência da maioria:

Estamos suficientemente inteirados para traçar um quadro aproximado da conduta de Maurício. Empenhava-se em conquistar partidários, mas não à maneira de Gelásio, mobilizando a opinião pública do mundo inteiro contra o rival. Pelo contrário, procurava, muito pela calada, com paz e sossego, assegurar a adesão

54 ERDMANN, Carl. O Papado e Portugal no Primeiro Século da História Portuguesa. Coimbra: Coimbra Ed., 1936 (Reimpressão em 1996), p. 20-21. 
de particulares, distribuindo ou prometendo lucros àqueles com quem estava relacionado pessoalmente. [...] Era um processo de pequena envergadura e que revelava timidez. Podia desistir de vencer o adversário. ${ }^{56}$ (Os grifos são nossos)

Fiel aos antepassados historiográficos, Erdmann fez a fraqueza moral do "antipapa" realçar o heroísmo moral do pontífice. De maneira negativa, o Burdino apresentado por sua escrita ensinava uma lição idêntica àquela antes protagonizada pelo Guiberto de Ravenna descrito por Gregorovius: a legitimidade de um papa evidenciava-se, acima de tudo, como uma força ética. Assim como as ações de Guiberto contrastavam com a inabalável firmeza dos princípios gregorianos, os poucos escritos deixados pelo pretencioso e curto exercício do governo papal por Maurício evidenciam, pelo contraste, a excepcional razão política de seu adversário. Afinal, suas cartas - disse Erdmann - retratavam a visão do mundo como um quebra-cabeça de minúsculas "relações pessoais", peças que o arcebispo só sabia unir através de contatos "privados" e "não muito competentes, pois nem Maurício, nem algum dos que o rodeavam, percebia patavina da técnica de redigir cartas". ${ }^{57}$ Não admira que o historiador alemão tenha se rendido à admiração: "que diferença dos manifestos belicosos e certos da vitória de Gelásio!". Neste, Erdmann encontrou o rigor moral e a impostação majestática que seus olhos não reconheceram em Maurício Burdino: "apesar de exilado, Gelásio desenvolveu, com energia e tato político, intensa atividade, capaz de abranger todo o orbis christianus". Cauteloso, "mas sempre calculista, acabou por vencer". ${ }^{58}$

Além da ênfase na supremacia universalista da consciência - "... capaz de abranger todo orbis christianus" -, Erdmann, aparentemente, partilhava outro princípio hegeliano, o que assegurava ser a "religião o elemento que melhor assegura a integridade do Estado". ${ }^{59}$ Embora tenha reconhecido que o arcebispo "trabalhou com zelo, em sentido reformador", o medievalista insistia em ver naquele "aventureiro" um homem que se destacava não pela espiritualidade ou pela intensidade da vida interior - como se esperava de um papa -; mas que ganhou relevo histórico por ter "possuído energia e habilidade na vida prática" ${ }^{60}$ No entanto, a deficiência de seu engajamento religioso parece figurar

$56 \quad$ Idem, p. 66.

$57 \quad$ Idem, p. 53-63.

$58 \quad$ Idem, p. 50.

59 HEGEL, Georg Wilhelm Friederich. Princípios da Filosofia... op. cit., p. 236.

60 Os dois trechos citados estão, respectivamente, em: ERDMANN, Carl. Maurício Burdino... op. cit., p. 10 e 8. Notese, igualmente, a conclusão da obra, estampada na página 72: "A habilidade para as coisas práticas e, ao que parece, 
entre as desrazões que o destinavam ao fracasso político. A sugestão não é improvável. Nascido sob o historicismo, Erdmann poderia seguir, ainda que às cegas, a premissa hegeliana que via na Igreja não somente algo interior à consciência, mas uma expressão sobre uma moral que apresenta as mais íntimas relações com os princípios políticos e as leis. ${ }^{61}$ Não pertencer aos quadros da religiosidade dominante da época era - nesta perspectiva - a grande causa da ilegitimidade dos antipapas. 0 pressuposto vicejou nas páginas da história do papado, nutrido por uma simbiose com o estereótipo da "Idade Média, Idade da Fé".

Anti-reforma, por isso "antipapa". O raciocínio silenciosamente construído alcança uma coerência irrepreensível. Sua trama pode ser resumida com facilidade. Nos século XI e XII a reforma eclesiástica predominava sobre o Ocidente, os ideais que a animavam eram senhores das consciências e condicionavam os rumos de quaisquer assuntos da/na Igreja. Da correção da rotina vivida num desconhecido monastério até a mais alardeada polêmica doutrinária cristã, tudo o que dizia respeito à ordem eclesial era tema da "Reforma". Logo, bastava ligar os pontos: a incapacidade dos "antipapas" em obter a aceitação como líder eclesiástico implicava, necessariamente, em uma condição marginal ou mesmo alheia à fé reformadora. Somente uma falha desse porte, reconhecidamente grave, poderia explicar as rejeições majoritárias oferecidas pela Igreja àqueles prelados. Nenhum fator correspondia a tal perfil como a indiferença ou a oposição à prática reformadora - aí está o pressuposto historiográfico. A derrota de Anacleto II, em meados da década de 1130, foi tomada como prova inconteste desta conclusão.

Se a Cúria foi gravemente dividida por divergência quando chegou o momento de eleger 0 sucessor de Honório II, em 1130, a razão era simples: os cardeais haviam formado dois grupos rivais, opostos por diferenças religiosas. A conclusão foi publicada por Hans-W. Klewitz em 1939. De um lado, havia o cardinalato antigo, composto por homens que conviveram com Urbano II e mantinham uma fidelidade marcial aos ideais dramaticamente defendidos por Gregório VII. Do outro, estava uma geração de novos cardeais: promovidos ao Sacro Colégio à apenas vinte anos, eles encaravam as ideias gregorianas como intransigências, verdadeiras relíquias de um conservadorismo que não

também a astúcia ajudaram-no a desempenhar um papel, que prometia ser muito brilhante, nas questões internas de Roma, sem, contudo, nelas conseguir penetrar. Quando sua estrela declinou no horizonte, todos o repudiaram. Afinal, só por um acaso é que ele foi personalidade histórica". 
possuía mais lugar entre os vivos. O primeiro grupo elegeu Pedro Pierleoni (autoproclamado Anacleto II), o segundo declarou-se por Gregório Papareschi (que tomou o nome de Inocêncio II). ${ }^{62}$

As acuradas críticas levantadas por Pier Palumbo em 1942 foram insuficientes para desbancar esta interpretação. ${ }^{63}$ No início dos anos 1960 ela voltou à tona, repaginada por Franz Josef Schmale. Segundo ele, a cisão dos cardeais em dois grupos eleitores rivais era a mais recente e visível escaramuça de uma guerra de concepções religiosas. A corte papal não estava dividida somente por diferenças de gerações, mais velhos versus mais novos; a separação por idades retratava compreensões divergentes acerca da fé. Os antigos estavam agarrados ao decadente monarquismo beneditino, encontrado em Cluny ou Monte Cassino, enquanto os jovens cardeais emprestavam influência e fortuna aos modelos reformadores recentemente fundados em Císter, na Cartuxa, em Prémontré, entre os cônegos regulares. Anacleto era a voz da resistência daquele monasticismo em crise. $^{64}$ Já a preferência por Inocêncio fora soprada para a sucessão papal pelos novos ventos da "Reforma". 65

Endossada por autores de respeitáveis contribuições aos estudos medievais, como Herbert Bloch, ${ }^{66}$ Adriaan Bredero, ${ }^{67}$ Stanley Chodorow ${ }^{68}$ e Jacqueline Bernard, ${ }^{69}$ esta tese atravessaria todo 0 século XX redizendo uma velha teleologia hegeliana: Anacleto estava derrotado antes mesmo de ser

62 KLEWITZ, Hans Walter. "Das Ende des Reformpapsttums," Deutsches Archiv für Geschichte des Mittelalters, vol. 3, 1939, p. 371-412.

63 PALMBO, Pier Fausto. Lo Scisma del MCXXX: I precedenti, la vicenda Romana e le ripercussioni europee della lotta tra Anacleto ed Innocenzo II col registro degli atti di Anacleto II. Roma: Miscellanea della R. Deputazione di Storia Patria, 1942.

64 A ideia da "Crise do Monasticismo Ocidental" contava, à época, com o respaldo de autores renomados do medievalismo: CANTOR, Norman. The crisis of Western monasticism, 1050-1130. American Historical Review, n. 66, vol. 01, 1960, p. 47-67; LECLERCQ, Jean. La crise du monachisme aux XI au XII siècle. In: HUNT, Noreen (Ed.). Cluniac Monasticism in the Central Middle Ages. Londres: Macmillan, 1971, p. 217-237.

SCHMALE, Franz-Josef: Studien zum Schisma des Jahres 1130. Böhlau, Köln U. A., 1961

66 BLOCH, Herbert. The Schism of Anacletus II and the Glanfeuil Forgeries of Peter the Deacon. Traditio, vol. 8, 1952, p. 159-264.

67 BREDERO, Adriaan. Cluny et Cîteaux au XIle siècle: les origines de la controverse. Studi Medievali, vol. 12, 1971, p. 135-176.

68 CHODOROW, Stanley. Christian Political Theory and Church Politics in the Mid-Twelfth Century: the ecclesiology of Gratian's Decretum. Los Angeles: University of California Press, 1972.

69 BERNARD, Jacqueline. Épiscopat et papauté chez saint Bernard de Clairvaux. Lille: Sainte-Marguerite-d'Elle, 1975. 
eleito, pois sua causa não estava identificada com as regras da "moralidade objetiva da época", isto é, o conjunto de princípios firmes e determinações objetivas que os indivíduos tomavam para si e reconheciam na forma de verdade, direitos e deveres coletivos. ${ }^{70}$

Eis aí uma definição perfeitamente coerente daquilo que tem sido designado como "projetos reformadores" medievais. Mais do que qualquer outra, a noção de um "programa reformador gregoriano" parece ilustrar esta correspondência de modo incomparável. Basta lembrar a imagem de política papal implicada neste conceito. Seu uso costuma induzir os historiadores a visualizar um grande círculo eclesiástico de homens de poder; todos unidos por um consenso sociologicamente tão extraordinário quanto historicamente implausível. Afinal, mesmo oriundos das mais díspares porções da Cristandade, ainda que distanciados por décadas inteiras e separados por identidades sociais conflitantes, os homens engajados neste arrojado "projeto reformador" comungariam do mesmo entendimento sobre a correta ordem da ecclesia, pois pensavam da mesma forma a respeito das transgressões e virtudes de um cristão. Entre eles não teriam existido discordâncias relevantes quando se tratava de identificar as infrações religiosas como a "simonia" ou o "nicolaísmo"; tampouco sobre as causas e medidas corretivas cabíveis.

Mas, o mais importante, ainda está por vir. Uma das principais induções acarretadas pela utilização da ideia de "projeto reformador" é justamente a premissa de encontrar nas diretrizes morais da "Reforma" as próprias coordenadas da conduta política dos agentes históricos implicados. Os princípios religiosos delimitariam o alcance das possibilidades de engajamento pelo poder. Portanto, as linhas de força da espiritualidade dos séculos XI e XII revelariam, para o medievalista, o traçado da arena em que eram travadas as lutas pela hegemonia ou resistência políticas. ${ }^{71} O$ vasto panorama do político é assim convertido em província do religioso, como apregoou certa vez um renomado medievalista. $^{72}$

Aí está o contorno essencial da resposta reiteradamente sacada pelos medievalistas para explicar as derrotas em seqüência daqueles atores políticos rotulados de "antipapas": encarados como

70 HEGEL, Georg Wilhelm Friederich. Princípios da Filosofia... op. cit., p. 121.

71 Tal concepção é amplamente predominante na literatura especializada, mas pode algumas referências podem ser elencadas como representativas de suas implicações: BARSTOW, Anne Llewellyn. Married Priests and the Reforming Papacy: the eleventh century debates. Nova York-Toronto: The Edwin Mellen Press, 1982; SWEENEY, James Ross. Gregory VII, the reform programme and the hungarian church at the end of the Eleventh Century, Studi Gregoriani, vol. 14, 1985, p. 265-275; FANNING, Steven. A Bishop and his World before the Gregorian Reform: Hubert od Angers, 1006-1047. Philadelphia: DIANE Publishing, 1988; MORRIS, Colin. The Papal Monarchy: the western church from 1050 to 1250. Oxford: Clarendon, 2001, p. 406. 
sujeitos completamente alheios à religiosidade reformadora, sua ascensão ao governo da Sé Romana aparece - por um pressuposto inteiramente teórico - condenada na escrita dos historiadores. Estes os julgavam vencidos antes mesmo que a disputa tivesse início. Na opinião destes estudiosos, aqueles agentes históricos sofriam de uma insuperável incapacidade de avaliar suas chances políticas. Afinal é o que sugerem os autores - eles eram figuras ineptas, malvistas por todos, marcados pela irreligiosidade e, por essa razão, desprovidos de qualquer meio eficaz para engendrar sentimentos de dever e obediência nos corações alheios.

\section{Categorias da Experiência Burguesa}

A separação entre "papas" e "antipapas" é um dos traços mais fortemente teóricos da historiografia medieval; é uma prova cabal de como as exigências conceituais dos olhos que lêem são capazes de domar as evidências documentais de modo conveniente - porque coerente - a certas expectativas intelectuais.

A evidente ilegitimidade dos "falsos pontífices" consistia numa presunção teórica ditada pela mistura de filosofia política hegeliana e de culto ao heroísmo papal como motor do progresso da História. Entre as décadas de 1040 e 1140, as disputas deflagradas por dois ou mais grupos pelo controle da lgreja de Roma inauguravam um tempo de instabilidades e incertezas que se arrastavam por meses, quando não por anos a fio. Seus desfechos foram, frequentemente, imprevisíveis para muitos daqueles que os testemunharam; talvez tenham mesmo sido decididos por acontecimentos improváveis. A legitimidade não estava dada de antemão: ela era o espólio do vencedor. Os vitoriosos escreviam uma memória conveniente dos fatos, eivada de esquecimentos - conforme as regras sociológicas próprias à operação memorialista. As acusações de erros, deméritos e infrações disparadas contra os derrotados manchavam igualmente as biografias dos "verdadeiros papas" contudo, foram silenciadas pelo retumbante alarido de seu triunfo. A legitimação é um acerto de contas que se faz com o passado após o desfecho da disputa, não antes.

Mas porque esta constatação - que não deixa de ser um mero apelo de historicidade - destoa tanto do estado da arte historiográfica? Porque tantos historiadores incorporaram em suas obras aquele controverso modelo narrativo? Por uma razão simples, mas em nada banal: os fundamentos da escrita da História não são exclusivamente intelectuais. Muito pelo contrário. Arriscamo-nos com a afirmação de que a estrutura de plausibilidade de uma versão do passado é construída, principalmente, a partir das dimensões e da complexidade que reconhecemos na condição humana através de nossas vivências cotidianas. Ao "medir" o passado, os historiadores o confrontam com certas possibilidades de 
existência, que são demarcadas objetivamente, com o respaldo documental, mas também subjetivamente, com os aspectos antropológicos e sociológicos da realidade a que eles próprios pertencem como homens e mulheres comuns. No caso dos estudos acerca do Papado dos séculos XI e XII, o segundo aspecto sobrepôs-se desmedidamente ao primeiro; as evidências empíricas foram inteiramente capturadas pelos sentidos de experiências sociais burguesas. E os "antipapas" foram devorados pelo "apetite biográfico" do século XIX:

O fato de aquela época sentir orgulho de seu domínio do passado tornava as biografias e histórias particularmente importantes como testemunhos da autoimagem burguesa. [...] Com o grande Leopold von Ranke à frente, historiadores profissionais chegavam a criticar os autores do lluminismo para exortar seus leitores a uma recuperação do passado em toda sua preteridade, em sua qualidade própria. Mas o faziam sob uma razão sintomática: transformando homens e mulheres na mais categórica afirmação da teoria histórica, em modelos heroicos, no interior dos quais era menos importante quem escolhiam para investigar do que a razão por que consideravam o elogio a eles necessário. ${ }^{73}$ (Os grifos são nossos)

Este desequilíbrio entre o referente histórico estudado e as expectativas conceituais dos estudiosos fez do passado receptáculo preenchido fundamentalmente com projeções irradiadas pela auto-realização dos autores em suas épocas. Suas palavras obscureceram a historicidade do pensamento que as regia. Sua escrita fez do objeto de estudos - a política papal medieval - um jogo de espelhos de uma única medida de mundo: a burguesa. Com isso, perdia-se de vista que o a compreensão do passado não é apenas apreensão de temas, mas aprender a conhecer nos indícios carregados pelo tempo a indivisível unidade entre o diferente e o semelhante daquele que conhece. Pensar historicamente é tecer relações entre a realidade da história e a realidade da compreensão histórica. Devemos, portanto, sempre "mostrar a realidade da história na própria compreensão" ${ }^{74}$

A História Medieval pagou alto preço para satisfazer esta exigência de transformar os vivos de outrora em "categóricas afirmações da teoria da história": a drástica redução de complexas trajetórias eclesiásticas a contrapostos de um idealizado modelo da liderança papal; a valorização desmedida da "Reforma" como fundamento da legitimidade do poder político, levando a espiritualidade às raias de raciocínios monocausais, plenos no risco de diluir a historicidade do passado. Paradoxalmente, este

73 GAY, Peter. O Coração Desvelado: a experiência burguesa da rainha Vitória a Freud. São Paulo, Cia das Letras, 1999, p. 168-177.

74 GADAMER, Hans-Georg. Verdade e Método l: traços fundamentais de uma hermenêutica filosófica. Petrópolis: Vozes, 2005, p. 396. 
esgotamento das possibilidades de realizaço política da História tornou-se a marca de uma herança hegeliana, fundadora de nossa moderna "consciência histórica".

\section{Bibliografia}

ANASTASIO, Ludovico A.. Istoria Degli Antipapi. Nápoles: S. Muziana, 1754.

ANNALES ALTAHENSIS MAIORES. MGH, SS. Rer. Germ., 2.

ANNUARIO PONTIFICIO. Roma: Tipographia Della R. C. A., 1861.

BALUZE, Étienne. Vita Mauritii Burdini archiepiscopi Bracarensis, em Miscellanea Historica, Ed. G. D. Mansi, Lucca, 1761.

BARSTOW, Anne Llewellyn. Married Priests and the Reforming Papacy: the eleventh century debates. Nova York-Toronto: The Edwin Mellen Press, 1982.

BARSTOW, Anne Llewellyn. Married Priests and the Reforming Papacy: the eleventh century debates. Nova York-Toronto: The Edwin Mellen Press, 1982.

BARONIO, Cesare. Annales Ecclesiastici. Londres: Typographi Editores, 1869.

BERNARD, Jacqueline. Épiscopat et papauté chez saint Bernard de Clairvaux. Lille: Sainte-Marguerited'Elle, 1975.

BERMAN, Harold. Law and Revolution: the formation of western legal tradition. Cambridge: Harvard University Press, 1984.

BLOCH, Herbert. The Schism of Anacletus II and the Glanfeuil Forgeries of Peter the Deacon. Traditio, vol. 8, 1952.

BOWDEN, John William. The Life and Pontificate of Gregory the Seventh. Londres: J. G. F. \& J. Rivington, 1840.

BREDERO, Adriaan. Cluny et Cîteaux au XIle siècle: les origines de la controverse. Studi Medievali, vol. $12,1971$.

BRUNDAGE, James. The Medieval Origins of Legal Profession: canonists, civilians and Courts. Chicago: Chicago University Press, 2006.

BRUNDAGE, James A. Law, Sex, and Christian Society in Medieval Europe. Chicago: The University of Chicago Press, 1987.

BUXTON, E. Wilmot. The Story of Hildebrand: Saint Gregory VII. Londres: Burns Oates \& Washbourn, 1920.

CAMERON, James Munro. Images of Authority: a consideration of the concepts of Regnum and Sacerdotium. Londres: Burns \& Oates, 1966.

CANTOR, Norman. The crisis of Western monasticism, 1050-1130. American Historical Review, n. 66, vol. 01, 1960, p. 47-67. 
CANTOR, Norman. Church, Kingship and Lay Investiture in England (1089-1135). Princeton: Princeton University Press, 1958.

LEYSER, Karl. Comunications and Power in Medieval Europe: the gregorian revolution and beyond. Londres: Continuum International Publishing Group, 1994.

CANTARELLA, Glauco. II Sole e la Luna: la rivoluzione di Gregorio VII papa, 1073-1085. Roma: Editori Laterza, 2005.

CANNING, Joseph. A History of Medieval Political Thought (300-1450). Nova York: Routledge, 1996.

CAPEFIGUE, Jean Baptiste Honoré Raymond. L'Église au Moyen Âge: du VIle au XIle siècle. Paris: Amyot, 1852, tomo I.

CAVALLARI, Vittorio. Cadalo e egli Erzoni. Studi Storici Veronensi, n. 15, 1965, p. 59-170.

CAPITANI, Ovidio. Immunità Vescovili ed Ecclesiologia in età "Pregregoriana" e "Gregoriana". Spoleto: Centro Italiano di Studi Sulla'Alto Medioevo, 1966.

CASTAGNETTI, Andrea. Fra I Vassalli: marchesi, conti, 'capitanei', cittadini e ruralli dalla documentazione del capitolo della cattedrale di Verona (século X-metá XII). Verona: Libreria Universitaria, 1999.

CENCI, Pio. Documenti inediti su la famiglia e la giovinezza dell'Antipapa Cadalo. Archivio Storico per le Province Parmensi, n. 23, 1923, p. 185-223; n. 24, 1924, p. 309-344.

CHÉLINI, Jean. Histoire Religieuse de l'Occident Médiéval. Paris: Hachette, 1991.

CHODOROW, Stanley. Christian Political Theory and Church Politics in the Mid-Twelfth Century: the ecclesiology of Gratian's Decretum. Los Angeles: University of California Press, 1972.

CODEX ULDARICI. In: JAFFÉ, P. (Ed.). Monumenta Bambergensia. Berlim: 1869.

COWDREY, Herbert Edward John. Popes, Monks, and Crusaders. Londres: Hambledon, 1984.

RAMOS, Luís Garcia-Guijarro. Papado, Cruzadas Y Ordenes Militares, siglos XI-XIII. Madri: Cátedra, 1995.

CORMENIN, Louis-Marie de Lahaye. The Public and Private History of the Popes of Rome. Londres: J. Campbell, 1846.

CUSHING, Kathleen. Papacy and Law in the Gregorian Revolution: the canonistic work of Anselm of Lucca. Oxford: Oxford University Press, 1998.

CUSHING, Kathleen. Reform and the Papacy in the Eleventh Century: spirituality and social change. Manchester; Nova York: Manchester University Press, 2005.

DAVID, Pierre. Études Historiques sur la Galice et le Portugal du Vle au XIle siècle. Coimbra: Gráfica Coimbra, 1947, sobretudo a conclusão das pp. 499-500.

DELARC, Odon. Saint Grégoire VII et la réforme de l'église au XIe siécle. Paris: Retaux-Bray, 1889, vol. 3.

DUPAS, Gilberto. O Mito do Progresso ou o Progresso como ideologia. São Paulo: Editora UNESP, 2006. 
DÖLLINGER, Johann Joseph Ignaz von. History of the Church. Londres: C. Dolman, 1841, vol. 3.

ERDMANN, Carl. Maurício Burdino (Gregório VIII). Coimbra: Coimbra Ed., 1940.

ERDMANN, Carl. O Papado e Portugal no Primeiro Século da História Portuguesa. Coimbra: Coimbra Ed., 1936.

FALCONIERI, Tommaso di Carpegina. "Popes through the looking glass or 'Ceci n'est pas un pape'”. Reti Medievali Rivista, vol. 13, n. 1, 2012.

FANNING, Steven. A Bishop and his World before the Gregorian Reform: Hubert od Angers, 1006-1047. Philadelphia: DIANE Publishing, 1988.

MORRIS, Colin. The Papal Monarchy: the western church from 1050 to 1250. Oxford: Clarendon, 2001. FLICHE, Augustin. La Réforme Grégorienne. Louvain: Spicilegium S. Lovaniense, 3 vol, 1924-1937, 3 vol.

FOULON, Jean-Hervé. Église et Réforme au Moyen Âge. Bruxelles: De Boeck, 2008.

FORNASARI, Giuseppe. Medioevo Riformato del Secolo XI: Pier Damiani e Gregorio VII. Nápoles: Liguori Editore, 1996.

GADAMER, Hans-Georg. Verdade e Método l: traços fundamentais de uma hermenêutica filosófica. Petrópolis: Vozes, 2005.

GAY, Peter. O Coração Desvelado: a experiência burguesa da rainha Vitória a Freud. São Paulo, Cia das Letras, 1999.

GREGOROVIUS, Ferdinand. History of Rome in the Middle Ages. Londres: George Bell \& Sons, 1986.

GFRÖRER, August Friedrich. Pabst Gregorius VII und sein Zeitalter. Leipzig: Schaffhausen, 1803-1861, $10 \mathrm{vol}$.

GUIBERTO DE RAVENNA, Epistolae et Privilegia. PL, 1882, tomo 148.

HAAKONSSEN, Knud (Ed.). The Cambridge History of Eighteenth-Century Philosophy. Cambridge: Cambridge University Press, 2006, vol. 2.

HEGEL, Georg Wilhelm Friedrich. Lectures on the Philosophy of World History. Cambridge: Cambridge University Press, 1975.

HEFELE, Ch. J. \& LECLERCQ, H.. Histoire des Conciles aprés les documents originaux. Paris: Letouzey et Ané, 1912-1915, tomo IV.

HEFELE, Charles Joseph \& LECLERCQ, Henry. Histoire des Conciles aprés les documents originaux. Paris : Letouzey et Ané, 1912-1915.

HEGEL, Georg Wilhelm Friederich. Princípios da Filosofia do Direito. São Paulo: Martins Fontes, 1997.

HENRION, Mathieu-Richard-Auguste. Histoire des Papes depuis Saint Pierre jusqu'à Grégoire XVI. Bruxelas: Société Nationale, 1838.

HEY, Richard. Some Principles of Civilization. Cambridge: Cambridge University Press, 1815. 
MAYBEL, Stephen. Civilization Civilized or The Process of Nationalization. Londres: Lovell, Gestefeld \& Company, 1892.

HERGENRÖTHER, Joseph. Handbuch der Allgemeinen Kirchengeschichte. Freiburg: B. Berlagshandlung, 1876.

HÖSLE, Vittorio. O Sistema Hegel: o idealismo da subjetividade e o problema da intersubjetividade. São Paulo: Loyola, 2007.

IOGNA-PRAT, Dominique. La Maison Dieu: une histoire monumentale de l'Église au Moyen Âge. Paris: Seuil, 2006; LAUWERS, Michel. Naissance du Cimetière: lieux sacrés et terre des morts dans l'occident medieval. Paris: Aubier, 2005.

JAFFÉ, Philippus; LOWENFELD, S. et alii (Ed.). Regesta Pontificum Romanorum. Leipzig: Veit, 18851888.

KANTOROWICZ, Ernst. Os Dois Corpos do Rei: um estudo sobre teologia política medieval. São Paulo: Cia das Letras, 1998.

KLEWITZ, Hans Walter. "Das Ende des Reformpapsttums," Deutsches Archiv für Geschichte des Mittelalters, vol. 3, 1939, p. 371-412.

LAMBERT, Malcolm. Medieval Heresy: popular movements from the Gregorian Reform to the Reformation. Oxford: Blackwell, 1977.

LAMBERTO DE HERSFELD. Annales. MGH SS. 5: 167-168.

LECLERCQ, Jean. La crise du monachisme aux XI au XII siècle. In: HUNT, Noreen (Ed.). Cluniac Monasticism in the Central Middle Ages. Londres: Macmillan, 1971, p. 217-237.

LE GOFF, Jacques. O Maravilhoso e o Quotidiano no Ocidente Medieval. Lisboa: Edições 70, 1987.

LEVILLAIN, Philippe (Ed.). Dictionnaire Historique de la Papauté. Paris: Fayard, 2003.

MANSI, Giovanni D. . Sacrorum Conciliorum nova et amplissima collectio. Veneza, 1758-1798.

MATTHEW, Arnold Harris. The Life and Times of Hildebrand: pope Gregory VII. Londres: Francis Griffiths, 1910.

MEYER VON KNONAU, Gerold Ludwig. Jahrbücher des Deutschen Reiches unter Heinrich IV. und Heinrich V. Leipzig: Duncker \& Humblot, 1890-1909.

MILEY, John. The History of the Papal States: from their origin to the present day. Londres: T. C. Newby, 1850, vol. 2.

MILLER, Maureen. The Bishop's Palace: architeture and authority in Medieval Italy. Ithaca: Cornell University Press, 2000.

MLLLER, Maureen. The Formation of a Medieval Church: ecclesiastical change in Verona (950-1150). Ithaca: Cornell University Press, 1993.

MILLER, Maureen Catherine. Power and the Holy in the Age of the Investiture Conflict: a brief history with documents. Boston: Bedford \& Saint Martin's, 2005. 
MOORE, Robert lan. The First European Revolution (970-1215). Oxford: Blacwell.

MORONI, Gaetano. Dizionario di Erudizione Storico-ecclesiastica da S. Pietro sino ai nostri giorni. Veneza: Tipografia Emiliana, 1840.

MORGHEN, Raphaello. Medioevo Christiano. Bari: Editori Laterza, 1962.

MURATORI, Ludovico Antonio. Dissertazioni sopra le Antichità Italiane. Milão: Società Tipografica de' Classici Italiani, 1837, vol. 5.

MULDOON, James. Empire and Order: the concept of Empire (800-1800). Nova York: Palgrave Macmillan, 1999.

MELVE, Leidulf. Inventing the Public Sphere: the public debate during the investiture contest (c.10301122). Leiden: Brill, 2 vol., 2007.

PACAUT, Marcel. La Théocratie: l'Église et le pouvoir au Moyen Age. Paris: Aubier, 1957.

PALMBO, Pier Fausto. Lo Scisma del MCXXX: I precedenti, la vicenda Romana e le ripercussioni europee della lotta tra Anacleto ed Innocenzo II col registro degli atti di Anacleto II. Roma: Miscellanea della R. Deputazione di Storia Patria, 1942.

PANVINIO, Onofrio. Romani Pontifices et Cardinales S. R. E. Ab eisdem a Leone IX apud Paulum papam IIII. Michaelem Tramezinum, 1557.

PEDRO DAMIÃO. Die Briefe. MGH Epp. Kaiserzeit, Briefe, tomo IV.

PEDRO DAMIÃO. Disceptatio Synodalis Inter Regis Advocatum et Romanae Ecclesiae Defensorem. PL, V. 145.

POOLE, Reginald L. . "Benedict IX and Gregory Vl", The Proceedings of the British Academy, 1917, vol. VIII.

PRODI, Paolo. Uma História da Justiça. São Paulo: Martins Fontes, 2005.

RANKE, Leopold von. History of the Popes of Rome, their Church and State. Londres: Henry G. Bohn, 1847, vol. 1.

RILEY-SMITH, Jonathan. The First Crusade and the Idea of Crusading. Londres: Continuum, 2003.

RORTY, Richard. Truth and Progress: philosophical papers. Cambridge: Cambridge University Press, 1998.

ROSENFIELD, Denis (Org.). Estado e Política: a filosofia política de Hegel. Rio de Janeiro: Zahar, 2003.

RUSCONI, R. II papa santo negli ultimi secoli del medioevo: tra Gregorio VII e Urbano V. In: MELVILLE, G. et alii (Ed.). Institution und Charisma. Köln: Boehlau, 2009.

RUST, Leandro Duarte. Colunas de São Pedro: a política papal na Idade Média Central. São Paulo: Annablume, 2011.

SCHWAIGER, Georg. "Grégoire VIII". In: LEVILLAIN, Philippe (Ed.). Dictionnaire Historique de la Papauté. Paris: Fayard, 2003

STROLL, Mary. Symbols As Power: The Papacy Following the Investiture Contest. Leiden: Brill, 1991. 
SCHMALE, Franz-Josef: Studien zum Schisma des Jahres 1130. Böhlau, Köln U. A., 1961.

SWEENEY, James \& CHODOROW, Stanley (Ed.). Popes, Teachers and Canon Law in the Middle Ages. Ithaca: Cornell University Press, 1989.

SWEENEY, James Ross. Gregory VII, the reform programme and the hungarian church at the end of the Eleventh Century, Studi Gregoriani, vol. 14, 1985.

SPRENGER, Kai-Michael. "The Tiara in the Tiber. An Essay on the damnatio in memoria of Clement III (1084-1100) and Rome's River as a Place of Oblivion and Memory". Reti Medievali Rivista, vol. 13, n. 1, 2012, p. 153-74.

TELLENBACH, Gerd. Church, State and Christian Society at the time of the Investiture Contest. Nova York: Harper Torchbooks, 1959.

TIERNEY, Brian. The Crisis of Church and State. Toronto: University of Toronto Press, 1988.

ULLMANN, Walter. Medieval Papalism. Londres: Methuen, 1949; Principles of Government and Politics in the Middle Ages. Londres: Methuen, 1961.

WILKS, Michael J. . The Problem of Sovereignty in the Later Middle Ages. Cambirdge: Cambridge University Press, 1963.

WITTE JR., John \& ALEXANDER, Frank S. (Ed.). Christianity and Law: an introduction. Cambridge: Cambridge University Press, 2008.

WITTE, John. God's Joust, God's Justice: Law and Religion in the Western Tradition. Grand Rapids: Wm. B. Eerdmans Publishing, 2006.

WATTERICH, J. M. (Ed.). Pontificum Romanorum Vitae. Leipzig:Guilhelmi Engelmani, 1860-1862, tomo I.

VAUCHEZ, André, A Espiritualidade na Idade Média Ocidental. Rio de Janeiro: Zahar, 1995.

VAUCHEZ, A.ndré (Ed.). Encyclopedia of Middle Ages. Cambridge: James Clark, 2000, vol. 1.

VILLEMAIN, Abel François. Histoire de Grégoire VII precedé d'un discours sur l'Histoire de la Papauté. Paris: Librarie Académique, 1835, vol. 2.

VOIGT, Johannes. Histoire du Pape Grégoire VII et de son siècle: d'aprés les monuments originaux. Paris: A. Vaton Editeur, 1838, vol. 2.

ZIGARELLI, D. M. Storia degli Antipapi e di Taluni Memorabili Avvenimenti delle Epoche rispettive dello Scisme. Nápoles: G. Gioja, 1859. 